\title{
DOES THE FORMAL FINANCIAL SECTOR ENHANCE SMALL BUSINESS EMPLOYMENT GENERATION IN NEPAL: EVIDENCE FROM CROSS-SECTIONAL DATA
}

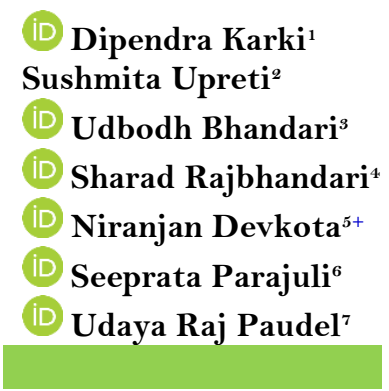

Article History

Received: 25 August 2021 Revised: 8 November 2021 Accepted: 3 December 2021 Published: 20 December 2021

\section{Keywords}

Financial support index Small business

Employment generation

Formal financial sector.

JEL Classification: D25; E32; F43; O43; Q56.

\author{
${ }^{\prime}$ Nepal Commerce Campus, Tribhuvan University, Kathmandu, Nepal.

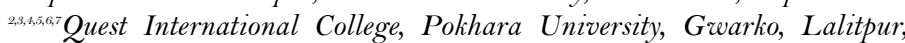 \\ Nepal. \\ Email:niranjandevkota@gmail.com

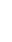 \\ (1)
} \section{4}


and development (Ghimire \& Abo, 2013). However, there is still a huge gap between banks' supply capacity and the demanding needs of small and medium-sized companies (Adhikari et al., 2021; Racheal \& Uju, 2018).

It is assumed that the small business sector will fill the gap in income generation and unemployment levels between the poor and the rich in developing countries. Productive small businesses are key drivers of economic development, including income growth and poverty reduction projects, in many developed countries (Delbiso, Deresse, Tadesse, Kidane, \& Calfat, 2018). Small business enterprises have generally earned little attention, despite providing employment for about three times the number of workers engaged in large-scale manufacturing, as well as playing a critical role in developing economies. Various opinions and studies have been published on the role that banks can play in funding and advising small enterprises in Nepal, since the federal government has shifted its policy to more strongly emphasize the self-reliance of small business enterprises. When banks support business and investment, employment opportunities are automatically generated. Banks make it possible for an economy to create employment opportunities (Rao, Kumar, Kalpana, \& Hymavathi, 2011).

A plethora of research has been carried out on small and medium sized enterprises' (SMEs) access to financing in the international context (Al-Harbi, 2019; Geissdoerfer, Vladimirova, \& Evans, 2018; Hallberg, 2000; Mac an Bhaird \& Lucey, 2011; Pfizer \& Krishnaswamy, 2007; Racheal \& Uju, 2018; Rungani \& Potgieter, 2018; Taiwo \& Falohun, 2016; Wangmo, 2016) as well as specifically in the Nepalese context (Adhikari et al., 2021); (Bista, 2019); (Pandey, 2016). In developing countries, more jobs are created by small and medium-sized enterprises (Hallberg, 2000). Also, small businesses play a major role in the Nepalese context Bista (2019). Further, as Racheal and Uju (2018) argued, access to formal credit can lead to an increase in production factors, which in turn can help to increase the SMEs' performance. Unfortunately however, due to small business owners' insufficient management knowledge and skills, they are unable to work successfully and efficiently enough to achieve their best possible performance (Al-Harbi, 2019). Pfizer and Krishnaswamy (2007) mentioned that financial companies, in various contexts, have paid little attention to the poor because the poor by definition have limited assets; informality, inadequate knowledge, inadequate infrastructure, and other obstacles have reinforced the perception that the poor cannot be commercially viable, much less an engine of innovation.

Still, the main obstacles to the development of high-growth SMEs are market failures in capital markets, weak government regulations, indirect labor costs, access to foreign markets, and difficulties recruiting skilled workers (OECD, 1996; Paudel \& Devkota, 2018; Paudel, Devkota, \& Bhandari, 2018). It has been noted that the primary problems of small businesses include access to finance, as well as business and support services that can help to effectively promote small businesses (Ihua, 2009). One of the biggest challenges being faced by policymakers is how best to establish a small business solution (Rungani \& Potgieter, 2018). In this context, modern banks play a vital role in a country's socio-economic issues (Rao et al., 2011). This study therefore focuses on identifying the support offered by the formal financial sector. The main objective of this paper is to identify the role of formal financial support in small business employment generation in Bouddhanath, Kathmandu. It will therefore examine the financial support index of the small business sector in Bouddhanath and the hurdles small business face in obtaining formal financial support.

The remainder of this paper is organized as follows: section two presents a review of the previous literature, followed by the research methodology in section three. The fourth section provides an overview and discussion of the results, and section five summarizes the conclusions of the study.

\section{LITERATURE REVIEW}

\subsection{Status of Small Businesses at Global and Local Levels}

Many previous studies have been carried out on SMEs' access to financing. According to Al-Harbi (2019), in order to ensure that SMEs continue to thrive, entrepreneurs around the world need to obtain the necessary management skills. Small business owners who have insufficient management information and skills cannot run 
their business successfully and efficiently enough to yield good outcomes.

Bista (2019) stated that Nepal's small businesses play a major role in creating jobs - in the manufacturing sector in particular - and contribute significantly to value added and export trade; however, Nepal's small business sector is embroiled in a number of problems. More generally, the fact that SMEs are the primary provider of jobs means that they help to resolve the difference between rich and poor, reduce social disparities and foster stability and economic growth; in developing economies, formally registered SMEs contribute up to $45 \%$ of employment and up to $33 \%$ of GDP, and counting the informal sector this proportion is substantially higher.

Pandey (2016) observed that bank lending rates have been varied in Nepal, due to the poor economic conditions of the country, armed conflict, and the global economic crisis. Due to the lower cost of capital, favorable lending rates helped entrepreneurs access loans. Researchers have noted that smaller companies face higher transaction costs in accessing credit than larger businesses and inadequate financing has been made available to support working capital; furthermore, weak management and accounting practices have hindered smaller businesses' ability to obtain financing (Taiwo \& Falohun, 2016).

\subsection{Importance of Small Businesses in Developing Countries}

Hallberg (2000) emphasized the high value of small and medium-sized enterprises in developing countries. Such companies have a highly significant role in creating jobs. Ecuador is an obvious example in this regard: in 1980, companies with fewer than 50 workers accounted for 95 percent of firms and 55 percent of employment. In Bangladesh in 1986, companies with fewer than 100 employees accounted for 99 percent of firms and 58 percent of employment (Nwosu, Osuagwu, Abaenewe, Ndugbu, \& Ayegba, 2016). By promoting intermediation, maturity transition, credit allocation, and payment structures with financial control, a sound financial system accelerates economic growth (Bista, 2019).

\subsection{Importance of Resources for the Success of Small Business and Some Theories Related to it}

Several theorists have weighed in on the issue of resources in small business. Rungani and Potgieter (2018) examined the importance of resources and capacities to a business, which help in fostering small business success. A business should have its own tools and sustainable competitiveness skills that other firms cannot copy. When entering the market with these resources and capabilities, businesses experience certain advantages and thus earn more profit, effectively enhancing the small business sector. Similarly, pecking order theory, as discussed by Racheal and Uju (2018), assumes that companies balance internal and external sources of funding through their relative availability and cost. In this regard, access to formal credit increases factors of production, helping to further increase the production.

Several other concepts have emerged in the context of this type of study. The life cycle model, as examined by Wangmo (2016), states that changes in a firm's development run parallel to the changes in its access to finances and changes in its capital structure. This model can be used as an effective predictive tool for long range planning. Likewise, Geissdoerfer et al. (2018) argue that the sustainable business model helps small businesses to innovate. Shifts in business models are recognized as a fundamental way of realizing sustainability innovations. Furthermore, in relation to the financial growth model, Mac an Bhaird and Lucey (2011) describe the growing array of financing options available to firms, on a continuum of size, age, and information, as they establish themselves and expand.

\section{MATERIAL AND METHODS}

\subsection{Study Area, Population and Sampling}

Kathmandu Valley is taken as the study area of the present research. This is the most advanced and populous area of Nepal. As the area includes the country's capital, banks have their head offices located in Kathmandu Valley (Bhandari et al., 2021). The Valley includes many offices and headquarters; it has become Nepal's economic hub 
(Adhikari et al., 2021). Its rich architecture and culture, which includes the largest number of jatras (street festivals) in Nepal, attract tourists. The Bouddhanath area, a major tourist destination and world heritage site, is specifically selected as the study area. The number of businesses in the study area is considerably larger than in other areas of the nation. Our main targeted population consists of banking professionals and small business holders, in order to obtain relevant data about the role of bank financing in employment generation.

The following formula was used to calculate the sample size: $\mathrm{n}_{0}=\left(\mathrm{z}^{2} \mathrm{pq}\right) / \mathrm{e}^{2}$ (Paudel, Parajuli, Devkota, \& Mahapatra, 2020). Where $\mathrm{n}_{0}=$ Sample size required for study, Standard tabulated value for $5 \%$ level of significance $(\mathrm{z})=1.96, \mathrm{p}=$ Prevalence or proportion of an event $50 \%=0.50$. So, $\mathrm{p}=0.50 \mathrm{q}=1-\mathrm{p}=0.50$. The allowable error that can be tolerated $(\mathrm{e})=6 \%$, Total population for the study $\mathrm{n}_{0}=\mathrm{Z}^{2} \mathrm{pq} / \mathrm{e}^{2}=(1.96)^{2} \times 0.5 \times 0.50 /(0.06)^{2}=266.78$. The non-response error was set at $5 \%$, i.e., $266.78 * 5 / 100=13.34$. Thus, the sample size taken for the study was $(266.78+13.34)=280.12 \sim 280$ at $6 \%$ error. Therefore, this study aimed to collect data from 285 small business holders in the Bouddhanath area.

\subsection{Research Instrument and Data Analysis Technique}

The primary tools used in this study are structured questionnaires, along with interviews and observations. To collect data from the small business owners and formal financial service providers we used Kobo Tool Box. Furthermore, to ensure the accuracy of the survey we pretested 24 samples from the total, i.e., $5 \%$. Data analysis was performed using descriptive analysis.

\section{RESULTS AND DISCUSSION}

\subsection{Socio-demographic Characteristics of Respondents}

The data on the gender composition of respondents revealed that $54 \%$ of respondents are male and $46 \%$ are female; also, only $4 \%$ were unmarried and the remaining 96\% were married. Nguyen (2014) mentioned that married owners are more likely to borrow from banks as well as non-traditional outlets such as rotating savings and loan associations. Of the 285 respondents, $65 \%$ were within the $30-40$ age range. In addition, education is one of the important factors that might influence the growth of a firm. High levels of human capital (education and experience) have been shown to have a positive impact in the growth of the firm (Tmava, Peci, \& Luboteni, 2013). The result of this study shows that $52.5 \%$ of the respondents had completed secondary education. Further information about the respondents' socio-demographic characteristics is depicted in Table 1.

Table-1. Socio-demographic characteristics of respondents.

\begin{tabular}{l|l|c|c|c}
\hline Field & & Male (\%) & Female (\%) & N (\%) \\
\hline Age (in years) & $20-29$ & 13.39 & 2.11 & 15.5 \\
\hline & $30-40$ & 36 & 29 & 65 \\
\hline & Above 40 & 13 & 42 & 19.9 \\
\hline Gender & Sex & 54 & 46 & 100 \\
\hline Marital Status & Married & 52 & 44 & 96 \\
\hline & Unmarried & 2.11 & 1.89 & 4 \\
\hline Level of Education & Primary & 10 & 10 & 20 \\
\hline & Secondary & 24 & 28.5 & 52.5 \\
\hline & Higher Secondary & 11 & 15 & 26 \\
\hline & Bachelors and above & 0.75 & 0.75 & 1.5 \\
\hline
\end{tabular}

\subsection{Major Issues Emerged in Operating the Business}

Regarding the major issues business owners reported facing in the course of operating their business, $31.22 \%$ of respondents noted the scarcity of available finance and other resources to run their business (Figure 1). In this regard, Tmava et al. (2013) asserted that small firms experience more difficulties in accessing external financing sources than larger firms, making them more dependent on internal funds to finance their investment needs. 
Similarly, coping with market competition (24.56\%); issues of quality management and growth (18.24\%); creating brand awareness (11.22\%); difficulties in adopting new technologies and other processes (9.12\%); and difficulties in managing the work force $(5.61 \%)$ are other issues reported by the respondents.

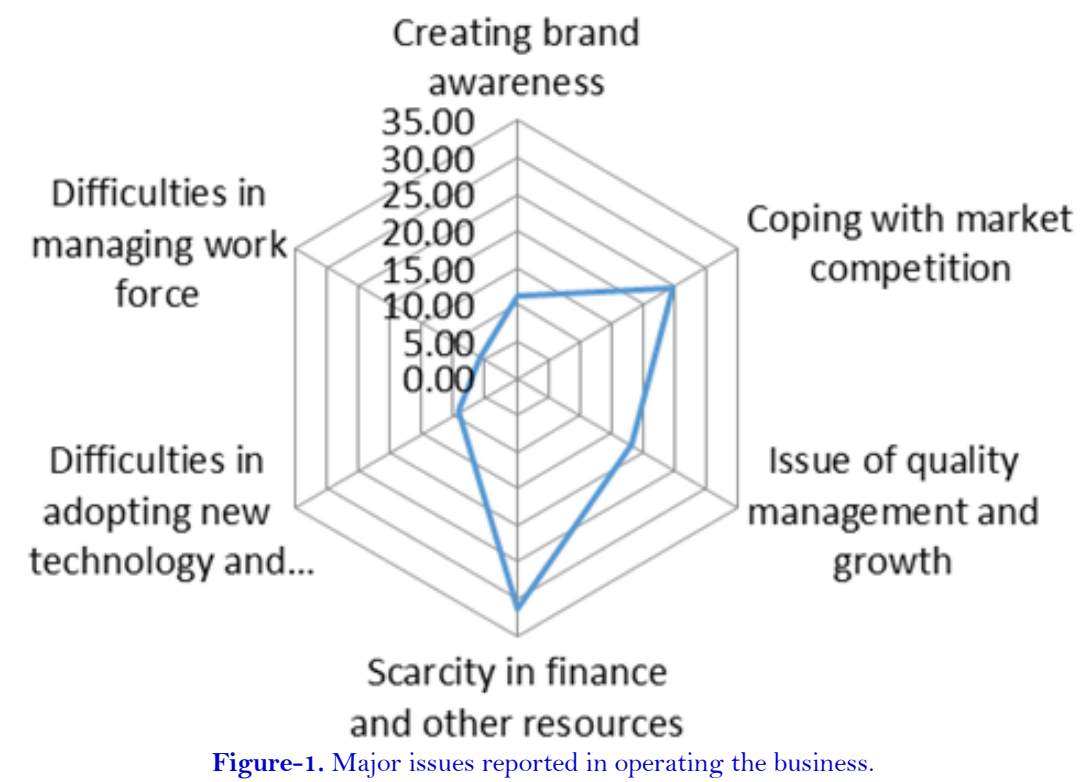

\subsection{Focus of Management Strategies}

Regarding the management strategies they are focused on, the respondents offered different opinions. The largest number of respondents (29.82\%) aimed to increase the sustainability of their business. Other focus areas of the respondents included maintaining proper business records (20.70\%); proper planning and evaluation of resources (15.08\%); knowing the key determinants of business challenges (14.73\%); and launching quality products $(10.52 \%)$ (Table 2). In this context, Ghimire (2012) has contended that although small business face different challenges, they remain a significant source of growth and development. In addition, 100\% of respondents noted that they operate their business with finance they have acquired. According to the survey results, the average cost of operating a small business is 24203.51 (ranging from 15000 to 50000 ).

Table-2. Focus of management strategies.

\begin{tabular}{l|l|c}
\hline S.N. & Factor & Response (\%) \\
\hline 1 & Making effort for sustainability of business & 29.82 \\
\hline 2 & Initiation on quality products & 10.52 \\
\hline 3 & Proper planning and evaluation of resources & 15.08 \\
\hline 4 & Maintaining proper records of the business & 20.70 \\
\hline 5 & Knowing the key determinants of business challenges & 14.73 \\
\hline 6 & Adopting new technologies & 9.12 \\
\hline
\end{tabular}

\subsection{Suggestions for the Improvement of the Small Business Sector}

Respondents suggested various ways of improving the small business sector. Most of the respondents (31.57\%) suggested keeping up-to-date in the business world. Other suggestions provided by the respondents included flexibility in business practices (14.38\%); embrace transparency (11.57\%); collaboration between small business and financial sectors (11.57\%); effective financial management (10.87\%); recognize and reward valuable contributions $(10.52 \%)$ (Table 3$)$. In these ways, financial and institutional development can help to close the gap between small and large firms (Beck \& Demirguc-Kunt, 2006). 
Table-3. Suggestions for the improvement of the small business sector.

\begin{tabular}{l|l|c}
\hline S.N. & Factors & Response (\%) \\
\hline 1 & Keep up to date in the business world & 31.57 \\
\hline 2 & Embrace transparency & 11.57 \\
\hline 3 & Flexibility in business practices & 14.38 \\
\hline 4 & Building a company culture & 9.47 \\
\hline 5 & Recognize and reward valuable contributions & 10.52 \\
\hline 6 & Effective financial management & 10.87 \\
\hline 7 & Collaboration between small business and financial sectors & 11.57 \\
\hline
\end{tabular}

\subsection{Impact of Pandemic on Business}

Respondents were also asked for their thoughts on the impact of the COVID-19 pandemic on business. Their responses included: decreased sources of income (53.33\%); operations negatively affected (30.87\%); supply chain disruptions (9.12\%); employee turnover (6.66\%) (Figure 2). In this context, the critical focus should be on job creation, domestic production and income collection (Subba, 2020).

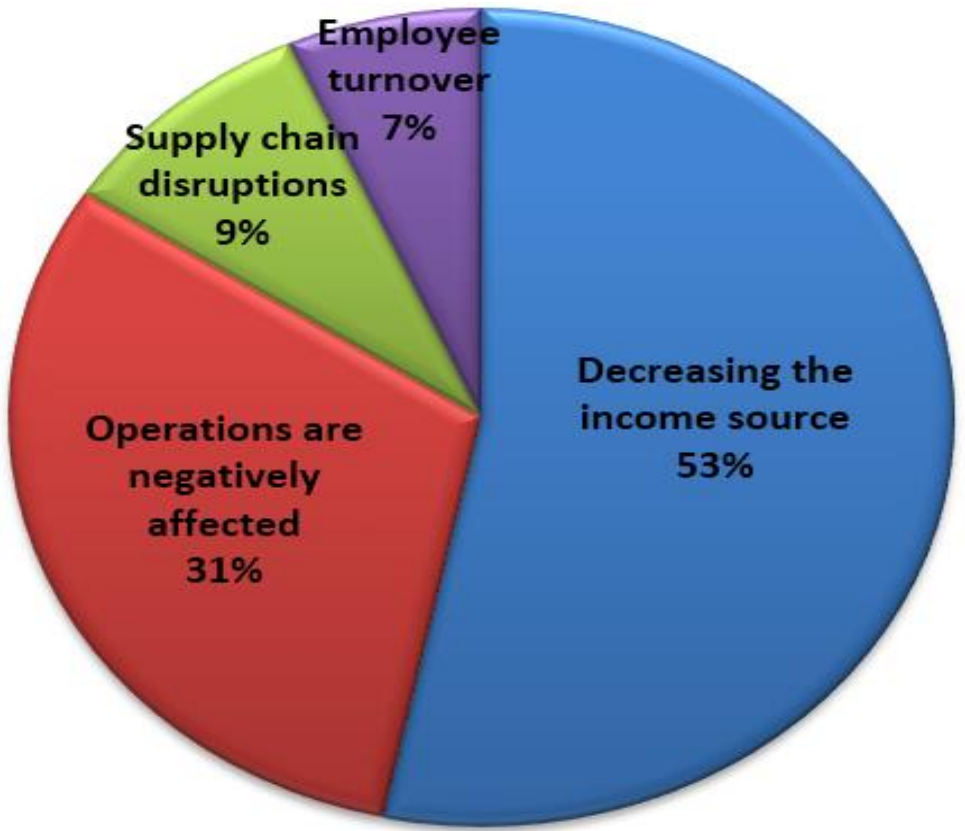

Figure-2. Impact of the COVID-19 pandemic on business.

4.6. Financial Support Level

To investigate the level of financial support, we have analyzed and considered various variables that further help to interpret the financial level that small business owners are operating at. In answer to the question of how a loan has supported their business, respondents replied: financial assistance to fulfill the varied needs of the enterprise (25.26\%); balancing quality and growth (15.08\%); ease in product enlargement (14.03\%); encourages mobilization of resources (12.28\%); helps in mobilization of business (10.52\%); effective business set up (7.01\%); maintaining variety of services (6.66\%); ease in decision making (5.61\%); and portfolio management services (3.50\%). Regarding the role of finance, White (2018) notes that access to finance is an essential prerequisite to enterprise growth.

\subsection{Financial Support Index}

Under financial support index, we have analyzed and considered various variables that help to gain a greater understanding of how the level of financial support affects small business enhancement. Table 4 shows the various questions asked of the respondents regarding their financial status. The results reveal that all the respondents are members of a bank, and $67 \%$ of respondents are members of a cooperative, while $33 \%$ are not. Almost all the 
respondents have at some point taken out a loan for their business operations. Expanding access to financial services has been shown to help reduce poverty and stimulate economic growth (Punya Savatsut, 2011). In addition, small and medium-sized enterprises (SMEs) in developing countries create jobs in both urban and rural areas and play a major role in the national economy and in social development (Quinn, 1997).

Table-4. Financial support index.

\begin{tabular}{|c|c|c|c|}
\hline S.N. & Financial Index & Yes (\%) & No $(\%)$ \\
\hline 1. & Are you a member of a bank? & 100 & $\mathrm{O}$ \\
\hline 2. & Are you a member of a cooperative? & 67.01 & 32.98 \\
\hline 3. & Have you taken out any loan for business? & 99.29 & 0.70 \\
\hline 4. & Have you taken out a business loan in the last 2 years? & 71.22 & 28.77 \\
\hline 5. & If not, have you ever taken out a business loan previously? & 28.77 & 71.98 \\
\hline 6. & Did you provide collateral for the loan? & 100 & $\mathrm{O}$ \\
\hline 7. & If yes, was your collateral sufficient to get a loan? & 100 & O \\
\hline 8. & $\begin{array}{l}\text { Has the loan received from a bank or financial institution helped } \\
\text { in the growth of your business? }\end{array}$ & 100 & O \\
\hline 9. & Did you achieve your desired goals after being granted the loan? & 100 & $\mathrm{O}$ \\
\hline 10. & Do you think your business enhances employment opportunities? & 100 & O \\
\hline
\end{tabular}

\subsection{Challenges of Small Businesses when Accessing Finance}

There are numerous challenges to the development of the small business sector in the country of Nepal. The results indicate that the majority of respondents has faced challenges regarding overreliance on credit $(51.4 \%)$. $21.5 \%$ of respondents experienced issues securing initial funding. Likewise, unexpected expenses (18.7\%); affording quality staff (8.4\%); and other mentioned challenges are considered to be the main hurdles in small business financing. $100 \%$ of respondents opined that such challenges affect their operation. $54 \%$ of them agree that the above-mentioned challenges impact their business operation very much, followed by considerably (37\%) and moderately (9\%). In this context, Racheal and Uju (2018) state that a lack of education on the part of SME owners and inadequate facilities in the agriculture, purchasing and supply sectors are significant challenges to SMEs. Respondents were asked whether such challenges can be minimized, and 100\% said that they could be.

\subsection{Minimizing the Challenges Faced in Business}

In response to the question about the ways to minimize the challenges faced in business, respondents' responses were: increasing investment (37.89\%); planning according to market demands and situations (31.22\%); changing business policy and strategy to match market demands (16.49\%); managing the work culture (7.36\%); and knowledge and understanding of cash management (Table 5). Moreover, Aribaba, Oladele, Ahmodu, and Yusuff (2019) contended that the tax policies have cut some of the incentives offered by the Industrial Enterprises Act for small-scale industries.

Table-5. Minimizing the challenges faced in business.

\begin{tabular}{l|l|c}
\hline S.N. & Factors & Response (\%) \\
\hline 1 & Planning for market demands and situations & 31.22 \\
\hline 2 & Knowledge and understanding of cash management & 6.66 \\
\hline 3 & $\begin{array}{l}\text { Changing business policy and strategy according to } \\
\text { market demands }\end{array}$ & 16.49 \\
\hline 4 & Increasing investment & 37.89 \\
\hline 5 & Managing the work culture & 7.36 \\
\hline
\end{tabular}

\subsection{Recommendation on the Contribution of Financial Institutions to Small Business Generation}

The survey results reveal the following recommendations provided by the respondents: financing businesses can lead to the success of small businesses (32.63\%); assistance with risk management (22.10\%); initiation of 
collaborative work (21.05\%); initializing the banking perspective (11.22\%); provide liquidity to economy (8.07\%); and strategic leadership (4.91\%) (Table 6).

Table-6. Recommendations for the Contribution of Financial Institutions

\begin{tabular}{l|l|c}
\hline S.N. & Factors & Response (\%) \\
\hline 1 & Financing businesses can lead to the success of small businesses & 32.63 \\
\hline 2 & Assistance with risk management & 22.10 \\
\hline 3 & Initiation of collaborative work & 21.05 \\
\hline 4 & Strategic leadership & 4.91 \\
\hline 5 & Initializing the banking perspective & 11.22 \\
\hline 6 & Provide liquidity to economy & 8.07 \\
\hline
\end{tabular}

\section{CONCLUSION AND RECOMMENDATIONS}

This paper offers insights into the various facets of small business access to finance. The Financial Support Index was used to analyze and consider various variables that may assist in depicting the role of the financial support level in small business enhancement. The results of this study reveal that most of the respondents keep their business records in a computerized system rather than on paper. The majority of business owners is involved in trade, rather than production or service delivery. The majority of the respondents accepts that there are certain challenges to accessing financial support for their business operation. The business owners indicate that there are certain factors that affect their business operation, such as overreliance on credit, securing initial funding and affording quality staff. Most business owners focus on financial assistance to fulfil the varied needs of their enterprises, as well as managerial solutions to their problems. According to the respondents, managerial solutions that can ensure effective small business operations include flexibility in business practices; strong collaboration, which can lead business growth; recognizing and rewarding valuable contributions; a clear vision and understanding of the business; increased efficiency and control of overheads; building a company culture and embracing transparency. Based on the findings of this study, we recommend that for small businesses to grow increased funding of the sector is required, along with flexibility in business practices. The financial sector must supply a wider variety of types of assistance in order to properly regulate business.

Funding: This study received no specific financial support.

Competing Interests: The authors declare that they have no competing interests.

Acknowledgement: All authors contributed equally to the conception and design of the study.

\section{REFERENCES}

Adhikari, D. B., Shakya, B., Devkota, N., Karki, D., Bhandari, U., Parajuli, S., \& Paudel, U. R. (2021). Financial hurdles in small business enterprises in Kathmandu Valley. Modern Economy, 12(6), 1105-1118. Available at: https://doi.org/10.4236/me.2021.126058.

Agbozo, E., \& Yeboah, E. O. (2012). Exploring the financial gap for small and medium-sized enterprises (SMEs) in Ghana: A case study of Ghana. 16(2), 40-47.

Al-Harbi, A. (2019). The determinants of conventional banks profitability in developing and underdeveloped OIC countries. Journal of Economics, Finance and Administrative Science, 24(47), 4-28. Available at: https://doi.org/10.1108/jefas-052018-0043.

Aribaba, F. O., Oladele, R., Ahmodu, A.-L. O., \& Yusuff, S. A. (2019). Tax policies and entrepreneurship sustainability in Ondo State, Nigeria. Journal of Global Entrepreneurship Research, 9(1), 1-13. Available at: https://doi.org/10.1186/s40497019-0168-0.

Beck, T., \& Demirguc-Kunt, A. (2006). Small and medium-size enterprises: Access to finance as a growth constraint. Journal of Banking E̊ Finance, 30(1 1), 2931-2943. Available at: https://doi.org/10.1016/j.jbankfin.2006.05.009. 
Bhandari, U., Jaisi, T., Devkota, N., Karki, D., Bahadur, D., Paudel, U. R., \& Parajuli, S. (2021). Retail loan under interest rate fluctuation in Nepal: Costumers' interest, challenges and managerial solutions. Journal of Asian Business Strategy, 11(1), 46-54. Available at: https://doi.org/10.18488/journal.1006.2021.111.46.54.

Bista, I. (2019). SMEs dinancing in Nepal: Five key findings of the report. Nepal Economic Forum. Retrieved from: https://nepaleconomicforum.org/neftake/smes-financing-in-nepal-five-key-findings-of-the-report/.

Delbiso, T. D., Deresse, F. N., Tadesse, A. A., Kidane, B. B., \& Calfat, G. G. (2018). Informal sector and urban unemployment: Small businesses contribution to large livelihood improvements. International Journal of Entrepreneurship and Small Business, 34(2), 169-182.

Geissdoerfer, M., Vladimirova, D., \& Evans, S. (2018). Sustainable business model innovation: A review. Journal of Cleaner Production, 198, 401-416.

Ghimire, A. J. (2012). Service quality and customer satisfaction in the restaurant business: Case study-Sagarmatha Nepalese restaurant in Vantaa. Degree Program, Central Ostrobothnia University of Applied Science.

Ghimire, B., \& Abo, R. (2013). An empirical investigation of Ivorian SMEs access to bank finance: Constraining factors at demand-level. Journal of Finance and Investment Analysis, 2(4), 29-55.

Hallberg, K. (2000). A market-oriented strategy for small and medium scale enterprises. International Finance Cooperation Discussion Paper Number 40.

Ihua, U. B. (2009). SMEs key failure-factors: A comparison between the United Kingdom and Nigeria. Journal of Social Sciences, 18(3), 199-207. Available at: https://doi.org/10.1080/09718923.2009.11892682.

Mac an Bhaird, C., \& Lucey, B. (2011). An empirical investigation of the financial growth lifecycle. Journal of Small Business and Enterprise Development, 10(10), 23-29.

Nguyen, N. T. (2014). Credit accessibility and small and medium sized enterprise growth in Vietnam. Doctoral Dissertation, Lincoln University.

Nwosu, M., Osuagwu, O., Abaenewe, Z., Ndugbu, M., \& Ayegba, S. F. (2016). Funding arrangements for small and medium scale enterprises (SMEs) in Nigeria: An assessment. Journal of Business Theory and practice, 4(1), 1-24. Available at: https://doi.org/10.22158/jbtp.v4n 1p1.

OECD. (1996). OECD employment outlook: July 1996. Paris, France: OECD.

Pandey, K. B. (2016). Impact of commercial banks' lending to small and medium scale enterprises on economic growth of Nepal. Economic Journal of Development Issues, 127-136. Available at: https://doi.org/10.3126/ejdi.v2 1i1-2.19026.

Paudel, U. R., \& Devkota, N. (2018). Socio-Economic influences on small business performance in Nepal-India open border: Evidence from cross-sectional analysis. Economics $\Theta^{2}$ Sociology, 11(4), 11-30. Available at: https://doi.org/10.14254/2071-789x.2018/11-4/1.

Paudel, U. R., Devkota, N., \& Bhandari, U. (2018). Socio-cultural and economic factors in cross-border purchase: A study of customers' perspective in Sunauli-Nepal/India Border. Modern Economy, 9(06), 1089-1102. Available at: https://doi.org/10.4236/me.2018.96070.

Paudel, U. R., Parajuli, S., Devkota, N., \& Mahapatra, S. K. (2020). What determines customers perception of banking communication? A piece of empirical evidence from commercial banks of Nepal. Global Economy Journal, 20(4), 1-21. Available at: https://doi.org/10.1142/s2194565920500190.

Pfizer, M., \& Krishnaswamy, R. (2007). The role of the food \& beverage sector in expanding economic opportunity. Corporate Social Responsibility. Kennedy School of Government, Harvard University Corporate Social Responsibilty Initiative Report No. 20.

Punya Savatsut, C. (2011). SMEs access to finance in Thailand. Small and Medium Enterprises (SMEs) Access to Finance in Selected East Asian Economies. In Harvie, C., S. Oum, \& D. Narjoko (eds.), Small and Medium Enterprises (SMEs) Access to Finance in Selected East Asian Economies (pp. 193-230). ERIA Research Project Report 2010-14, Jakarta.

Quinn, J. J. (1997). Personal ethics and business ethics: The ethical attitudes of owner/managers of small business. Journal of Business Ethics, 16(2), 119-127. 
Racheal, J.-A. C., \& Uju, M. (2018). The role of commercial banks in financing small \& medium size enterprises in Nigeria. European Journal of Business, Economics and Accountancy, 6(3), 1-23. Available at: https://doi.org/10.46281/ijfb.v 1i1.82.

Rao, K. S., Kumar, M. K. P., Kalpana, M. K., \& Hymavathi, M. C. (2011). Indian SMEs global competitiveness. International Journal of Management, 2(2), 01-06.

Rungani, E. C., \& Potgieter, M. (2018). The impact of financial support on the success of small, medium and micro enterprises in the Eastern Cape province. Acta Commercii, 18(1), 1-12. Available at: https://doi.org/10.4102/ac.v18i1.591.

Subba, S. (2020). Unlocking the economy post-lockdown. Nepali Times. Retrieved from: https://www.nepalitimes.com/latest/unlocking-the-economy-post-lockdown/.

Taiwo, J., \& Falohun, T. O. (2016). SMEs financing and its effects on Nigerian economic growth. European Journal of Business, Economics and Accountancy, 4(4), 37-54.

Tmava, Q., Peci, F., \& Luboteni, G. (2013). The role of banks in small and medium enterprises financing: A case study from Kosovo. International Journal of Economics and Finance, 5(12), 94-103. Available at: https://doi.org/10.5539/ijef.v5n12p94.

Wangmo, C. (2016). Small and Medium Enterprise (SME) financing constraints in developing countries: A case study of Bhutan. Doctoral Dissertation, Victoria Universit.

White, S. (2018). Creating better business environments for micro and small enterprises (pp. 55-60). Cambridge: Technical Report, Donor Committee for Enterprise Development.

The views and opinions expressed in this article are the views and opinions of the author(s). The Journal of Social Economics Research shall not be responsible or answerable for any loss, damage or liability caused in relation to/arising from the use of the content. 